\title{
ROMANIA IN AND AFTER THE GREAT WAR: UNDERGROUND FACTS AND MYSTERIES
}

\author{
Assist. Prof. Florian Olteanu, \\ University of Craiova, Faculty of Social Sciences, A.I.Cuza, Street, No.13, \\ 200585, Craiova, Dolj County, Romania. \\ *florianolteanu19@gmail.com
}

Keywords: mystery, underground facts, secret diplomacy, Great War, Romania

The participation of Romania at the First World War is one of the most important facts from its entire history. But there are a lot of facts which reveal some underground facts and mysteries. Romania was in 1914 secretly associated in the Triple Alliance (Central Powers) even one of the allies, AustriaHungary refused any consideration concerning the problem of Romanians in the double monarchy. The Russian Empire succeeded to get close on Romanian diplomacy, in June 2014, after a visit of Tsar Nicholas II at Constanta, even King Charles I of Romania was member of a German dynasty and Romania and Germany were relied in the Central Powers alliance. In Romania, the "Russophobe feeling" after the War of 18771878 took some higher quotes, but politicians had kept secret the alliance with AustriaHungary (this secret treaty signed in October 30 1883, was known only by the King, his President of the Ministers Council and the Ministry of Foreign Affairs).Romania refused to join Austria-Hungary after this member of Central Powers declared war on Serbia in July 28 1914, a month after the assassination of Heir Prince Franz Ferdinand of Austria-Hungary. Romania said that were not accomplished the conditions of "casus belli" the because AustriaHungary was not aggressed being the aggressor, which cancelled the Treaty article referring to "casus belli".

It was curios that Italy adopted the neutral position (it was a founder of the Central Powers Alliance) in the same time with Romania. Another mystery was the weakness of the Romanian secret service structures.
The reports sent by general Iliescu to the President of Ministers Council Ion I.C. Brătianu had presented a false situation that of a non-aggressive attitude of Bulgaria if Romania will pass the Carpathian Mountains if a convention with Triple Entente (France, Great Britain Russia) should be concluded. In August 1916, Romania declared war on Austria-Hungary.

The campaign has a successfully starting, but at Turtucaia, Romanian Arrmy was defeated by German and Bulgarian forces. Until December 1916, Romania was occupied by Central Powers, and the government, the King and the Parliament went in refugee in Iasi, Moldavia.

The Romanian treasury was transferred in Russia, but another mystery represents the fact if Romanian Government was informed on the crisis from Russia (in February 1917 has started the Russian Revolution). The Tsar presented his dismissal in the spring of 1917. In April 1917, parts of Romanian treasury continued to be transferred in Russia, even Lenin presented the "Thesis of April" and the Tsar and his family were placed under domicile arrest, in the Ural Mountains region.

Romania defended itself in the summer of 1917 against German attacks, but the Russian Counterrevolution from October 1917 succeeded to withdraw Russia from the war in March 1918. In the period October 1917March 1918, even Romania was territorially reduced at Moldavia (in Bucharest was installed a Pro-German government under the presidency of the Conservative Party Leader Alexandru Marghiloman). 
Between Romania and Central Powers was signed a temporary armistice in Focșani. Russian Empire was in dissolution and the Romanians from Bessarabia asked for help at Bucharest and Iasi. German authorities gave the permission to Marghiloman to initiate the unity of Bessarabia with Romania, but put pressure of a separate peace. General Alexandru Averesecu, the hero of Mărăști battle from the summer of 1917 had a duplicity attitude. He signed an accord with the Bolshevik leader Christian Rakowski in which he accepted a «tactically retreat" of the Romanian Army from Bessarabia (later this act was almost seen as a treason, because the Bolsheviks tried a strike in Iasi in which intended to assassinate the Romanian King Ferdinand and Queen Mary).

Later at the signing of the Bucharest Peace (April 24/May 7 1918), Alexandru Averescu had an attitude of opposition. After the capitulation of Bulgaria and Austria-Hungary, on November 10 1918, Romania declared war on Germany, but on November 11-th 1918, Germania signed the unconditional surrender. Romania was in the "victorious camp" and
Alexandru Averescu will play, after the Great Union of 1918 (in November and December 1918, Bucovina, Transylvania, Banat had united with Romania) a major political role (being manoeuvred by Ion IC Brătianu as Prime Minister of an artificially political party Peoples Party).

At the Peace Conferences of 1918, Ion IC Brătianu was helped by another Romania patriot Alexandru Vaida Voevod to counterattack the opposition of France, Great Britain, Italy, USA which considered that Romania could not sign the separate peace in May 1918 and which considered Romania as a vanquished country. Even names as Queen Mary, Martha Bibescu and other important figures had difficult discussions with Georges Clemenceau the French Prime Minister representing at the Peace Conferences known as "The Tiger" concerning the international recognition of the Great Union of 1918.

These are some of the mysterious and underground facts of the Great Union of 1918 which would be clarified by this key-note presentation

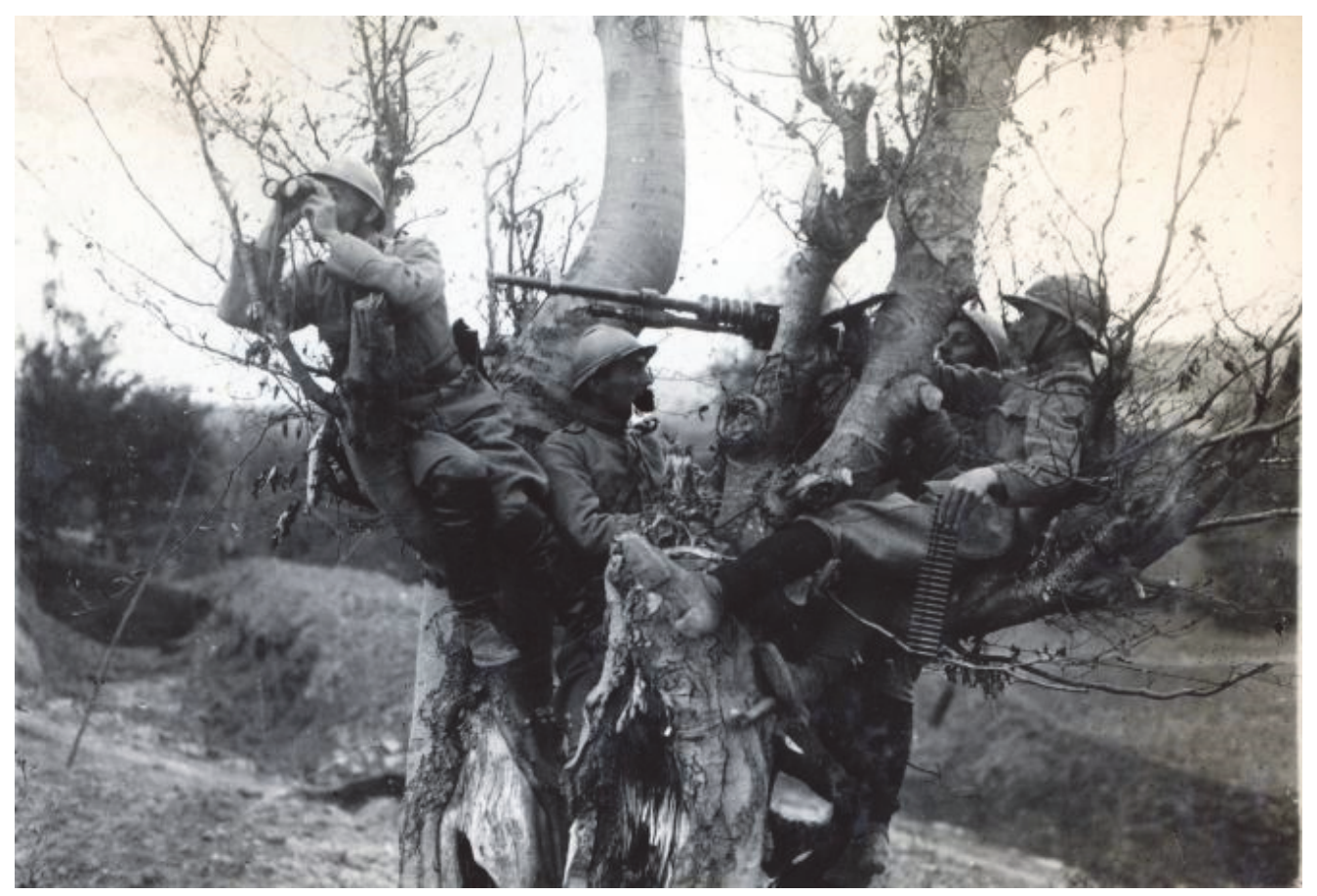

